GEOGRAFICKÝ ČASOPIS / GEOGRAPHICAL JOURNAL 70 (2018) 4, 351-371

DOI: https://doi.org/10.31577/geogrcas.2018.70.4.19

\title{
NOVÉ PRÍSTUPY K HODNOTENIU PROCESU POPULAČNÉHO STARNUTIA A ICH APLIKÁCIA V PRÍPADE SLOVENSKA A EURÓPY
}

\author{
Branislav Šprocha*, Luděk Šídlo**, Michaela Klapková**, Pavol Ďurček*** \\ * Centrum spoločenských a psychologických vied SAV, Šancová 56, 81105 Bratislava, \\ INFOSTAT - Výskumné demografické centrum, Leškova 16, Bratislava, branislav.sprocha@gmail.com \\ ** Univerzita Karlova, Př́rodovědecká fakulta, Katedra demografie a geodemografie, Albertov 6, 12843 Praha 2 , \\ ludek.sidlo@natur.cuni.cz, michaela.klapkova@gmail.com \\ *** Univerzita Komenského v Bratislave, Prírodovedecká fakulta, Katedra humánnej geografie a demografie, \\ Ilkovičova 6, Mlynská dolina, 84215 Bratislava, pavol.durcek@uniba.sk
}

\begin{abstract}
New approaches to assessing the population ageing process and their application for Slovakia and Europe

Population ageing is one of the most important phenomenon of the 21 st century. This is especially true for the Slovak population. According to almost all population projections and analyzes, the population ageing process of Slovakia will become more dynamic in the next few years. All these studies of population ageing focus on only one characteristic of people - their chronological age. Many important characteristics do not depend on the number of lived years, but on the number of years that a person will live. A new set of indicators of population ageing are based on the concept of prospective age. In comparison to traditional measures they do not use the number of years a person has already lived, but the number of years that a person will probably live. The main aim of this paper is to present the new concept of a prospective age and to introduce new indicators that enable us to analyze the process of population ageing in a new dimension. Supplementing chronological age with an approach that takes into account the changing life expectancy allows us to analyze ageing more comprehensively and more accurately.
\end{abstract}

Key words: prospective age, demographic ageing, new approaches to population ageing, life expectancy adjusted measures, Slovakia

\section{ÚVOD}

Populačné starnutie predstavuje bezprecedentný proces, ktorý nemá $\mathrm{v}$ histórii l'udstva obdobu (UN 2001). Stalo sa dôležitou sociálnou, ekonomickou, zdravotníckou a dokonca aj kultúrnou témou v dôsledku rozsahu svojich dosahov a svojej takmer univerzálnej prítomnosti (Lutz et al. 2008a). Špecifická kombinácia klesajúcej úmrtnosti a plodnosti viedla k zrýchleniu starnutia obyvatel'stva vo väčšine spoločností vrátane rozvojových krajín (Lutz et al. 2008b). Podl'a správy World Population Ageing 2015 (UN 2015) v podstate každá krajina na svete čelí nárastu počtu a podielu starších osôb v populácii. Proces populačného starnutia sa stáva jedným z najvýznamnejších spoločenských transformačných javov 21. storočia s vplyvom takmer na všetky sektory spoločnosti (UN 2015), preto je často aj odbornou verejnost'ou vnímaný ako fenomén či kl'účová otázka nového milénia (napr. Gavrilov a Heuveline 2003 a Lutz et al. 2008b).

Podobne aj na Slovensku sa populačné starnutie stalo jednou z ústredných tém nielen demografie, geodemografie, sociológie, ekonómie, ale aj d'alších viac či menej príbuzných vedných disciplín. Rovnako vel'kú pozornost' tejto otázke venujú médiá a často je diskutovaná aj v širšej verejnosti. Pri určitom zovšeobecnení však 
prevláda pomerne negatívne nazeranie na túto problematiku spájané predovšetkým $\mathrm{s}$ hrozbami prameniacimi $\mathrm{z}$ budúceho vývoja udržatel'nosti dôchodkového systému, systému zdravotného zabezpečenia, ako aj úbytku pracovných síl. Hoci proces zvyšovania počtu a podielu osôb považovaných za starých na Slovensku prebieha viacmenej dlhodobo, až dramatické a dynamicky sa presadzujúce zmeny reprodukčného správania posledného štvrt'storočia prispeli k intenzifikácii diskusií a samotného vedeckého záujmu o túto problematiku. Platí však to, na čo v zahraničí v spojitosti s výskumom procesu starnutia upozorňovali Sanderson a Sherbov (2007). Kým záujem o proces populačného starnutia dramaticky vzrástol, v kontraste s tým prístupy, ako aj nástroje používané na jeho analýzu sa v podstate nijako výraznejšie nezmenili. Možno povedat', že všetky nám známe práce zo Slovenska, a to nielen z oblasti demografie a geodemografie, sa v podstate opierajú o klasické na chronologickom veku založené analytické indikátory. Tie konceptualizujú a využívajú fixnú podobu veku, ktorá je inertná voči zmenám v čase, priestore a teda aj medzi populáciami. Takýto prístup napríklad imanentne očakáva, že dnešní starí l'udia (ktorých vyčleňuje vekom $60+$ alebo $65+$ rokov) na Slovensku sú rovnakí ako tí pred pät'desiatimi, či dokonca pred sto rokmi. Ako uvádza Sanderson a Scherbov (2007), aplikáciou chronologického veku implicitne predpokladáme, že osoby rovnakého veku žijúce $\mathrm{v}$ populácii v rôznych obdobiach budú mat' rovnaké charakteristiky a budú sa správat' rovnako. Pritom nie všetky charakteristiky sú viazané na počet prežitých rokov. Viaceré a mnohé dokonca vel'mi dôležité charakteristiky (napr. stratégie spojené so šetrením, investíciami, nadobúdaním vzdelania, poskytovanie určitých foriem zdravotného ošetrenia a zdravotníckych výkonov a pod.) sa odvíjajú od počtu zostávajúcich rokov života (Sanderson a Scherbov 2007, 2008, 2010, 2013 a 2015). Je preto potrebné si uvedomit', že každá osoba, každá populácia má nielen chronologický (retrospektívny) vek, ale aj tzv. prospektívny vek. Ten predstavuje počet rokov, ktorý osobe, resp. skupine osôb zostáva ešte prežit' podl'a daných úmrtnostných podmienok. Retrospektívny a prospektívny prístup umožňujú analyzovat' obe dimenzie veku a procesu populačného starnutia. Pros-pektívny pohl'ad a na ňom založené nové indikátory starnutia tak nemajú za úlohu nahradit' klasické nástroje, ale vytvárajú priestor na ovel'a hlbšie a komplexnejšie skúmanie tohto fenoménu (Sanderson a Scherbov 2007).

Ciel'om predloženého článku je predstavit' nový koncept nazerania na vek a populačné starnutie prostredníctvom prospektívneho veku, objasnit' jeho metodické pozadie, ako aj identifikovat' $\mathrm{z}$ neho odvodené alternatívne nástroje umožňujúce hodnotenie novej dimenzie procesu populačného starnutia. Súčasne sa pokúsime uvedené indikátory aplikovat' na populáciu Slovenska v dlhodobom časovom horizonte, a to aj s prihliadnutím na možné vývojové aspekty do budúcnosti. Okrem toho poukážeme na medzinárodný kontext oboch dimenzií veku a starnutia, a to s prihliadnutím na postavenie Slovenska v európskom priestore. Na rozdiel od nášho predchádzajúceho článku (Klapková et al. 2016) sa snažíme uvedené indikátory aplikovat' primárne na populáciu Slovenska v dlhej časovej perspektíve. Nejde pritom len o súčasný stav a retrospektívny vývoj, ale dôraz kladieme aj na možné budúce smerovanie procesu starnutia. Dôležitým prínosom článku je tiež jedinečná a $\mathrm{v}$ podstate aj ojedinelá orientácia na európske prostredie (EU28) aplikáciou oboch dimenzií veku a procesu starnutia s prihliadnutím na postavenie Slovenska. 


\section{TEORETICKO-METODICKÝ VSTUP DO PROBLEMATIKY PROSPEKTÍVNEHO VEKU}

Sledovanie chronologického veku znamená zamerat' sa len na jeden z meniacich sa aspektov populačného starnutia. $\mathrm{V}$ dôsledku toho je náš pohl'ad značne obmedzený, často dokonca skreslený a limitujúci pre d’alšie vedecké analýzy alebo konštruktívne politické rozhodnutia (Sanderson a Scherbov 2013). V pozadí chronologického veku pritom existujú viaceré d’alšie dimenzie, ktorých zahrnutie poskytuje širší a komplexnejší pohl'ad na proces populačného starnutia. Ide napríklad o zostávajúcu strednú dlžku života, zdravotný stav a morbiditu, miery postihnutia či kognitívne funkcie (Sanderson a Scherbov 2013).

Samotná myšlienka prospektívneho pohl'adu na vek v spojitosti s procesom starnutia nie je vo svojej podstate úplnou novinkou a začala sa rozvíjat' už v 70. rokoch minulého storočia. Dlho však zostávala bez väčšieho záujmu. Až posledných 10 - 15 rokov prinieslo skutočný rozmach prospektívneho pohl'adu na vek a populačné starnutie. Rozhodujúcou mierou k tomu prispela predovšetkým dvojica Warren C. Sanderson a Sergei Scherbov. V roku 2005 publikovali v časopise Nature (Sanderson a Scherbov 2005) svoj prvý príspevok k danej problematike a v nasledujúcich (napr. Sanderson a Scherbov 2007, 2008, 2010, 2013 a 2015 a Scherbov a Sanderson 2016) ho d'alej rozpracovávali. V nadväznosti na ne alebo v priamej spolupráci s autormi sa problematike začali venovat' aj d'alší autori (napr. Lutz et al. 2008a a 2008b, Lutz 2009, Basten et al. 2015, Riffle 2015 a Spijker 2015). Nezávisle od dvojice Sanderson a Scherbov bol prospektívny prístup tiež znovuobjavený v prácach autorov Shoven (2007) a Shoven a Goda (2010). Z československého prostredia sa otázke prospektívneho veku podl'a našich poznatkov zatial' venovali len dve štúdie: Cuaresma et al. (2014) a Klapková et al. (2016).

Prečo je prospektívny pohl'ad na vek taký dôležitý a prečo v posledných rokoch zažíva takú renesanciu? Predovšetkým je to akútnost' problematiky starnutia, ktorú pocit'ujú všetky moderné a postmoderné spoločnosti. Okrem toho je potrebné si tiež uvedomit', že koncept chronologického veku sa s predlžovaním života stáva komplikovanejším a menej vhodným na analýzu procesu starnutia, ked’že l’udia majú pred sebou v porovnaní so svojimi predchodcami čoraz viac rokov života (Sanderson a Scherbov 2008). V dôsledku predlžovania života je napríklad zavádzajúce porovnávat' súčasné osoby s chronologickým vekom 40 rokov s osobami vo veku 40 rokov pred viac ako polstoročím. Navyše stredná dížka života sa nemení len pri pohl'ade na vývoj v čase, ale je výrazne odlišná pri medzinárodnom porovnaní, či na regionálnej úrovni. Indikátory populačného starnutia založené na chronologickom veku tieto variácie neberú do úvahy (Sanderson a Scherbov 2008). Vzhl'adom na uvedené zmeny a problémy Sanderson a Scherbov (prvýkrát v roku 2005) navrhli nový koncept pohl'adu na vek a starnutie. Hlavnou inovatívnou myšlienkou tohto prístupu je vnímanie dvoch dimenzií veku u každej osoby. Jeden predstavuje klasický, konvenčný chronologický vek, čiže počet človekorokov, ktoré osoba už od svojho narodenia prežila. Druhým je prospektívny vek založený na počte človekorokov, ktoré osoba môže očakávat', že ešte prežije do svojej smrti. Ide v podstate o tzv. zostávajúcu strednú dížku života.

Základnou črtou prospektívneho veku tak je, že ide o konzistentný časový horizont, pretože všetci l'udia s rovnakým prospektívnym vekom majú rovnaký očakávaný počet rokov pred sebou, bez ohl'adu na už prežitý časový interval (Sanderson a Scherbov 2007). V podstate ide o chronologický vek očistený od zmeny strednej 
dížky života. Konvenčné, na chronologickom veku založené prístupy k starnutiu môžu tento proces dobre vystihovat' len v situáciách, ked' úmrtnost' zostáva v čase (prípadne medzi sledovanými populáciami) rovnaká. Populačné starnutie však nie je len výsledkom poklesu plodnosti, ale aj predlžovania života. Potvrdzujú to nielen výskumy $\mathrm{z}$ demograficky najvyspelejších populácií sveta, ale aj z viacerých rozvojových krajín (Oeppen a Vaupel 2002 a Bongaarts 2006). Preto vhodnejším ako fixné stanovenie vekovej hranice je premýšl'at' o veku prospektívne v kontexte zostávajúcich rokov alebo $\mathrm{v}$ pomere $\mathrm{k}$ predlžujúcej sa dlžke života (Sanderson a Scherbov 2005). To znamená jednoznačne rozšírit' náš prístup o prospektívny pohl'ad pri analýze veku a populačného starnutia. Nutnost' pracovat' s dvomi konceptmi veku je spojená aj s niektorými d'alšími charakteristikami osôb. Tie s rastúcim chronologickým vekom prestávajú byt' od neho závislé. Čoraz viac sú pritom v správaní l'udí zohl'adňované počty zostávajúcich rokov života. Je minimálne problematické očakávat', že napríklad súčasné osoby vo veku 60 rokov sa budú rovnako správat', budú mat' rovnaké charakteristiky (zál'uby, preferencie, správanie, kognitívne vlastnosti, zdravie a pod.) ako tak isto „staré“ osoby na začiatku 20. storočia. Tento prístup je pritom už bežne zohl'adňovaný napríklad v zdravotníctve (pri náhrade kolenného kĺbu, ked' sa zohl'adňuje, či operácia môže signifikantne zvýšit' počet rokov pacientovej mobility) - pozri Sanderson a Scherbov (2007). Rovnako sa ukazuje, že vel'mi citlivo na počet zostávajúcich rokov života reagujú výdavky spojené so zdravotnou starostlivost'ou. Platí pritom, že predovšetkým v posledných rokoch života sa výrazne zvyšujú (Sanderson a Scherbov 2007 a 2013). S predlžovaním života sú však tieto roky posúvané do čoraz vyššieho chronologického veku. Preto nezohl'adnenie zmien strednej dížky života môže prinášat' skreslené až absurdné predikcie budúcich nákladov spojených so zdravotnou starostlivost'ou (Sanderson a Scherbov 2007 a 2013).

Asi najjednoduchšie je možné koncepciu prospektívneho veku predstavit' na názornom príklade. Predstavme si dve priemerné osoby vo veku 50 rokov žijúce na Slovensku v rokoch 2016 a 1900. Obidve teda prežili od svojho narodenia 50 rokov a v klasickom vnímaní procesu starnutia ide teda o „rovnaké“ osoby. Kým v roku 1900 však táto osoba mala podl'a úmrtnostných tabuliek pred sebou približne 20 rokov, v súčasnosti je to už približne 29 rokov. Ak rok 1900 použijeme ako štandard, potom rovnakú strednú dlžku života (29 rokov) ako dosahujú dnešní pät'desiatnici dosahovali vtedajší štyridsiatnici. Môžeme tak povedat', že súčasný pät'desiatnik je minulý štyridsiatnik, resp. osoba vo veku 50 rokov má prospektívny vek 40 rokov.

Tab. 1. Schéma odvodenia prospektívneho veku $\mathrm{z}$ retrospektívneho veku a strednej dížky života

\begin{tabular}{|c|c|c|c|c|}
\hline \multicolumn{2}{|c|}{ Úmrtnostná tabul'ka pre sledovaný rok (t) } & \multicolumn{3}{|c|}{ Úmrtnostná tabul'ka pre štandardný rok (s) } \\
\hline $\begin{array}{l}\text { Retrospektívny vek } \\
(\mathrm{X})\end{array}$ & $\begin{array}{c}\text { Stredná dížka života } \\
\text { vo veku }(\mathrm{X}) \mathrm{e}_{(\mathrm{X})}\end{array}$ & $=$ & $\begin{array}{l}\text { redná dližka života } \\
\text { vo veku }(\mathrm{Y}) \mathrm{e}_{(\mathrm{Y})}\end{array}$ & $\begin{array}{c}\text { Prospektívny vek } \\
(\mathrm{Y})\end{array}$ \\
\hline \multicolumn{2}{|c|}{ Úmrtnostná tabul'ka pre rok 2016} & \multicolumn{3}{|c|}{ Úmrtnostná tabul'ka pre štandardný rok 1900} \\
\hline 50 rokov & $\mathrm{e}_{(50)}=29$ rokov & $=$ & 29 rokov $=\mathrm{e}_{(40)}$ & 40 rokov \\
\hline
\end{tabular}


Použitie prospektívnych analytických indikátorov procesu starnutia výraznejšie nezat’ažuje používatel'a. Tie zostávajú nielen l'ahko konštruovatel'nými, ale aj interpretačne prístupnými. Postupne bolo zostavených niekol'ko prospektívnych indikátorov. V našej práci predstavíme a budeme aplikovat' tie najdôležitejšie a najčastejšie používané.

Najjednoduchším konvenčným indikátorom je počet, resp. podiel starých osôb čiže osôb, ktoré dosahujú určitý chronologický vek. Najčastejšie je takto zvolený vek 60 alebo 65 rokov. Ako uvádzajú Atchley (1982) a Basten et al. (2015), hranica 65 rokov súvisí s reformami sociálneho systému z prelomu 19. a 20. storočia, ked’že nad touto úrovňou mali vo viacerých najvyspelejších krajinách osoby nárok na štátne penzijné dávky (pozri napr. OECD 2011). Išlo o hrubú aproximáciu, ktorá však dlho umožňovala pomerne dostatočne presne porovnávat' starnutie populácií v čase i priestore. Ak odhliadneme od pôvodného kontextu, ked' táto hranica staroby vznikala, potom k jej hlavným kritickým bodom v súčasnosti môžeme priradit': výrazne vyšší počet a podiel osôb, ktoré sa dožijú veku 65 rokov, ovel'a dlhší život, ktorý osoby majú ešte pred sebou v tomto veku, ako aj zdravotný stav (a d'alšie charakteristiky) týchto osôb (Basten 2013). Enormná variabilita hodnôt dĺžky života medzi populáciami vo vyššom veku, a to nielen v čase, ale aj medzi jednotlivými krajinami, znamená, že fixná hodnota hranice staroby vyjadrená chronologickým vekom už nemôže reflektovat' v dostatočnej miere realitu (Sanderson a Scherbov 2008). Indikátory, ktoré nezohl'adňujú túto variabilitu stredných dížok života, môžu abstrahovat' od zásadných charakteristík starnutia. Teda už nejde len o to, že l'udia sú v populácii starší (z hl'adiska chronologického veku), ale hlavne o to, že títo starší l'udia sú zdravší, vzdelanejší, majú lepšie kognitívne schopnosti, sú inou mentálnou kohortou a $\mathrm{v}$ neposlednom rade majú pred sebou v priemere viac rokov života ako ich predchodcovia (Sanderson a Scherbov 2008). Alternatívny prístup prináša prospektívny pohl'ad zameriavajúci sa na budúcnost', pričom do popredia vstupuje potenciálny počet rokov, ktoré osoby môžu ešte prežit'. Za hranicu staroby plne vystihujúcej hlavné dimenzie populačného starnutia z prospektívneho pohl'adu bol stanovený vek, $\mathrm{v}$ ktorom osobám zostáva ešte prežit' 15 rokov života (Sanderson a Scherbov 2008). Táto hodnota bola empiricky odvodená z úrovní strednej dížky života vo veku 65 rokov v krajinách s nízkou úmrtnostou (pozri Sanderson a Scherbov 2015). Výhodou zostávajúcej strednej dížky života ako hranice staroby je, že bez ohl'adu na populáciu, priestor a čas bude podl'a úmrtnostných tabuliek takto definovanej skupine osôb vždy zostávat' na prežitie ešte určitý počet rokov. Aj v našej práci preto budeme využívat' takto definovaný konštantný prospektívny vek (CPA, RLE 15, Constant Prospective Age, RLE 15-age). $\mathrm{Z}$ neho je následne možné odvodit' percentuálne zastúpenie osôb so strednou dĺžkou 15 a menej rokov z celej populácie (Prop. RLE 15-, Proportion at Ages With Remaining Life Expectancies of 15 Years or Less). Výhodou konštantného prospektívneho veku je, že odpadá nutnost' pracovat' s úmrtnostnými tabul'kami sledovaného a štandardného (referenčného) roku a odvodzovat' túto veličinu ich prostredníctvom (pozri vyššie v tab. 1). Postačuje len úmrtnostná tabul'ka pre sledovaný rok a z nej je prospektívny vek $(Y)$ vypočítaný prostredníctvom nasledujúceho vzt'ahu:

$$
Y=X_{0}+\left(e_{X 0}-e_{Y}\right) \frac{\left(X_{0}-X_{1}\right)}{\left(e_{X 0}-e_{X 1}\right)}
$$


kde $X_{0}$ je chronologický vek (veková skupina) pred dosiahnutím prospektívneho veku, $X_{1}$ je chronologický vek (veková skupina) po dosiahnutí prospektívneho ve$\mathrm{ku}, e_{Y}$ je stredná dížka života $\mathrm{v}$ prospektívnom veku (v tomto prípade $=15$ rokov), $e_{X 0}$ je stredná dížka života $\mathrm{v}$ chronologickom veku $X_{0}$ (hodnota vyššia ako 15 rokov) a $e_{X I}$ je stredná dlžka života $\mathrm{v}$ chronologickom veku $X_{1}$ (hodnota nižšia ako 15 rokov).

Jedným z najstarších indikátorov starnutia je index (ekonomickej) závislosti. Prvýkrát ho pred viac ako 100 rokmi predstavil vedeckej obci nemecký ekonóm a štatistik Carl Ballod (1913). Vo svojich prácach Sanderson a Scherbov (2008, 2013, 2015) navrhli alternatívu. My sa zameriame na ich verziu týkajúcu sa starého obyvatel'stva. Vo všeobecnosti index závislosti starého obyvatel'stva (old-age dependency ratio - $O A D R$ ) predstavuje jednoduchý nástroj vyvinutý na demonštrovanie vzt'ahu medzi početnou vel'kost'ou starej zložky obyvatel'stva a osôb v produktívnom veku. V čase sa postupne menili vekové hranice vymedzujúce horný i dolný interval, pričom zvlášt' bývali definované aj pre mužov a ženy v závislosti od nastavenia veku odchodu do starobného dôchodku. Vzhl'adom na predlžovanie štúdia sa ako spodná hranica produktívneho veku dnes začína používat' vek 20 rokov. Rovnako v dôsledku zjednotenia a predlžovania odchodu do starobného dôchodku a čoraz častejších snáh zostávat' v pracovnom procese aj vo vyššom veku je horná hranica produktívneho veku posunutá do veku 64 rokov. V súvislosti s tým však Sanderson a Scherbov (2015, p. 688) namietajú, že to, akým chronologickým vekom je produktívna a poproduktívna zložka ohraničená, je druhoradé. Najdôležitejšou vlastnost'ou (a súčasne slabinou) akýchkol'vek indikátorov veku založených na počte prežitých rokov je to, že sú konceptualizované a konštruované použitím fixného chronologického veku, ktorý je nezávislý na mieste, čase, populácii či charaktere samotnej závislosti (Sanderson a Scherbov 2015). Alternatívou ku klasickému indexu závislosti starého obyvatel'stva je potom indikátor, ktorý vo svojom výpočte zahŕňa zmeny v strednej dížke života. Jeho autori Sanderson a Scherbov (2008) ho označili ako prospektívny index závislosti starého obyvatel'stva (prospective old-age dependency ratio - POADR). V zmysle uvedenej hranice starého obyvatel'stva prostredníctvom zostávajúcej strednej dĺžky života 15 rokov môžeme $P O A D R$ vyjadrit' nasledujúcim vzt'ahom:

$$
P O A D R=\frac{P_{X(R L E 15-)}}{P_{20-X(R L E>15)}} .100,
$$

kde $P_{X(R L E 15-)}$ je počet osôb vo vekoch so zostávajúcou strednou dížkou života 15 a menej rokov a $P_{20-X(R L E>15)}$ je počet osôb vo veku od 20 rokov do veku, kde stredná dížka života je stále ešte väčšia ako 15 rokov.

Analogicky potom $\mathrm{k}$ indexu starnutia, ako k pomeru starej a mladej zložky obyvatel'stva, je možné vyjadrit' aj prospektívny index starnutia (prospective aging index-PAI):

$$
P A I=\frac{P_{x(R L E 15-)}}{P_{0-19}} .100,
$$

kde $P_{X(R L E 15-)}$ je počet osôb vo vekoch so zostávajúcou strednou dížkou života 15 a menej rokov a $P_{0-19}$ je počet osôb od narodenia do dokončeného veku 19 rokov (vrátane). 
Okrem indexov sú na vyjadrenie vekovej štruktúry a starnutia populácie používané aj stredné hodnoty. Najčastejšie ide o syntetické indikátory v podobe priemerného veku a vekového mediánu. Ich konštrukcia zohl'adňujúca zmeny v strednej dížke života je už o niečo komplikovanejšia. Ukazovatel' PARYL (population average remaining years of life) je alternatívou k priemernému veku. Ide v podstate o vážený priemer zostávajúcich stredných dížok života, pričom váhou je podiel osôb v každej príslušnej vekovej skupine. Jej autor Hersch (1944) spolu s Panushom a Peritzom (1994) predpokladali, že priemerná osoba v určitom veku $(x)$ má potenciálny počet rokov života totožný so strednou dížkou života $\left(e_{x}\right)$ $\mathrm{v}$ tomto veku. Ak vekové rozloženie sledovanej populácie je dané $\left(P_{x}\right)$, potom pre potenciálne roky života $(P A R Y L)$ môžeme odvodit' vzt'ah:

$$
P A R Y L(P Y L)=\frac{1}{2} \cdot \sum_{x=0}^{\omega} P_{x} \cdot\left(e_{x}+e_{x+1}\right) \text {. }
$$

$P A R Y L$ nám tak dáva priemerný počet zostávajúcich rokov života jedného „,priemerného“ člena sledovanej populácie. Na rozdiel od ostatných indikátorov veku a populačného starnutia, hodnoty $P A R Y L$ klesajú s prehlbujúcim sa procesom starnutia. Je to logická vlastnost', pretože čím v priemere viac rokov života majú pred sebou osoby v populácii, a teda hodnota $P A R Y L$ je vyššia, tým je sledovaná populácia mladšia (Lutz 2009).

Jedným z často reflektovaných znakov prehlbujúceho sa procesu populačného starnutia vo vyspelých krajinách sveta je kontinuálny rast hodnôt mediánového veku (Gavrilov a Heuveline 2003). Ten vo svojej klasickej podobe rozdel'uje populáciu na dve rovnaké časti. Polovica osôb má vek nižší ako je hodnota mediánového veku a polovica je naopak staršia (z hl'adiska chronologického veku). Prospektívna podoba mediánového veku je definovaná ako prospektívny vek osoby v mediánovom veku, pričom svojou konštrukciou je o niečo komplikovanejšia ako predchádzajúce indikátory veku. Jeho výpočet spočíva v niekol'kých krokoch. Prvým je určenie štandardného roku (a prípadne aj populácie pre medzinárodné analýzy) a k nemu prislúchajúcej štandardnej úmrtnostnej tabul'ky. Tento krok je dôležitý na zachovanie porovnatel'nosti hodnôt prospektívneho mediánu, ked’že priamo odvodenú strednú dlžku života v mediánovom veku pre každý rok, resp. pre každú populáciu, nie je priamo možné na tieto účely použit'. Často je z týchto dôvodov zvolená prvá alebo posledná dostupná reálna hodnota, pričom pri medzinárodných komparáciách býva napríklad štandardom úmrtnostná tabul'ka Švédska (pozri Klapková et al. 2016). Pre naše účely sme zvolili úmrtnostnú tabul'ku Slovenska z roku 2016. V d’alšom kroku je vypočítaný klasický vekový medián sledovanej populácie. K nemu je z úmrtnostných tabuliek odvodená mediánová stredná dížka života. V úmrtnostnej tabul'ke štandardu sa následne pre príslušnú hodnotu mediánovej strednej dížky života určí chronologický vek. Ten je pre analyzovanú populáciu prospektívnym mediánovým vekom. Môžeme teda povedat', že prospektívny mediánový vek je vek osoby vo zvolenej štandardnej populácii, v ktorom má rovnakú strednú dížku života ako osoby v mediánovom veku v analyzovanej populácii (tab. 2). 
Tab. 2. Schéma odvodenia prospektívneho mediánového veku

\begin{tabular}{|c|c|c|c|c|}
\hline \multicolumn{2}{|c|}{ Analyzovaná populácia } & \multicolumn{3}{|c|}{ Štandardná populácia } \\
\hline $\begin{array}{l}\text { Mediánový vek } \\
\text { (X) }\end{array}$ & $\begin{array}{l}\text { Mediánová stredná } \\
\text { dížka života }\left(\mathrm{e}_{\mathrm{X}}\right)\end{array}$ & $=$ & $\begin{array}{l}\text { Stredná dížka života } \\
\text { štandardu }\left(\mathrm{e}_{\mathrm{Y}}\right)\end{array}$ & $\begin{array}{c}\text { Prospektívny mediánový } \\
\text { vek (Y) }\end{array}$ \\
\hline
\end{tabular}

Vstupnými údajmi pre výpočet jednotlivých konvenčných na retrospektívnom veku založených indikátorov populačného starnutia a prospektívnych ukazovatel'ov boli dlhé časové rady počtu obyvatel'ov Slovenska podl'a jednotiek veku a podrobné úmrtnostné tabul'ky pre obdobie rokov 1950 - 2016. Predikovaný vývoj sledovaných indikátorov po roku 2016 sa opiera o výsledky kmeňovej prognózy obyvatel'stva Slovenska do roku 2060 (Bleha et al. 2013).

\section{PREDLŽOVANIE ŽIVOTA, PROSPEKTIIVNY VEK A POPULAČNÉ STARNUTIE NA SLOVENSKU}

$\mathrm{S}$ pokrokom v medicíne, zdravotníctve, zmenami v epidemiologickej situácii, zvyšovaním povedomia zodpovednosti za vlastné zdravie súvisí aj predlžovanie života a zmena počtu rokov, ktoré má (môže) osoba v určitom veku ešte prežit'. Ako ukazujú Oeppen a Vaupel (2002), Vallin a Meslé (2004), Bongaarts (2006) a d'alší, po druhej svetovej vojne sme vo vyspelých krajinách svedkami kontinuálneho zlepšovania úmrtnostných pomerov a tým aj predlžovania života. V populáciách s nízkou úmrtnost'ou sa priemerné ročné predĺženie života pohybuje od 60 . rokov 20. storočia na úrovni 0,20 (Sanderson a Scherbov 2004) až 0,25 roka (Oeppen a Vaupel 2002). Priaznivý vývoj úmrtnostných pomerov však môžeme s výnimkou obdobia od konca 60 . do konca 80 . rokov 20. storočia sledovat' aj na Slovensku. Napríklad na začiatku 20. storočia by sa pri zachovaní intenzity úmrtnosti len približne štvrtina mužov mohla dožit' 65. roku života (pozri Śsprocha a Majo 2016). Po druhej svetovej vojne by to bola necelá polovica, no podl'a posledných údajov z roku 2016 sú to už viac ako tri štvrtiny mužov. Ako však uvádzajú Sanderson a Scherbov (2008) a Basten et al. (2015), vel'mi dôležitým a do určitej miery aj prekvapivým javom $\mathrm{v}$ populačnom vývoji je neslabnúci rastúci trend v zostávajúcej dížke života aj vo veku 65 rokov. Vzhl'adom na nízku intenzitu dojčenskej a detskej úmrtnosti, ako aj značné vyčerpanie potenciálu v mladom a strednom produktívnom veku, zostáva pre budúci vývoj rozhodujúcim práve smerovanie úmrtnostných pomerov $\mathrm{v}$ staršom produktívnom a najmä poproduktívnom veku. Hoci medzi vedcami neexistuje jednoznačný konsenzus v otázke dynamiky a celkovej úrovne tohto vývoja, nie je vo všeobecnosti takmer žiadny dôvod na očakávanie výraznejšieho spomal'ovania pozitívneho vývoja úmrtnostných pomerov (Bongaarts 2006). Pravidelné prírastky stredných dížok života vo vyšších vekových kategóriách sa vo viacerých krajinách sveta stávajú normou (Sanderson a Scherbov 2008).

Rovnakú situáciu môžeme pozorovat’ aj na Slovensku. Súčasný 65-ročný muž má pred sebou približne rovnaký počet rokov života $(15,2$ roku) ako 60-ročný muž žijúci na Slovensku po druhej svetovej vojne alebo 55-ročný muž zo začiatku 20. storočia. Pozitívny vývoj úmrtnostných pomerov sa očakáva aj v d’alších desat'ročiach. Podla populačnej prognózy Blehu et al. (2013), ako aj najnovšej prognózy EUROSTAT-u (2015) by sa stredná dížka života mužov pri narodení v roku 2060 
mohla dostat' na úroveň $81-85$ rokov a v prípade žien by to mohlo byt' $84-89$ rokov (podl'a variantu prognózy). Rovnako aj u osôb vo veku 65 rokov sa predpokladá kontinuálne predlžovanie života, a to až na $20-23$ rokov u mužov a $22-26$ rokov u žien.

Obr. 1 prezentuje koncept prospektívneho veku na príklade Slovenska v dlhom časovom horizonte, a to nielen smerom do minulosti, ale aj do budúcnosti. V druhom prípade sa opierame o stredný variant predikcie úmrtnostných pomerov použitý v kmeňovej prognóze Blehu et al. (2013). Ako štandard bola zvolená hodnota zostávajúcej strednej dížky života z roku 2016 vo vybraných vekoch $(30,40,50$, 60,65 a 70 rokov). Línie čiar tak v čase spájajú chronologické veky, v ktorých táto potenciálna dížka života bola, resp. bude podl'a prognózy rovnaká. Vzhl'adom na stagnáciu úmrtnostných pomerov na Slovensku od polovice 60 . do konca 80 . rokov 20. storočia sa hodnoty prospektívneho veku pre toto obdobie príliš nemenili. $\mathrm{S}$ nástupom kontinuálneho znižovania úmrtnosti od začiatku 90. rokov 20. storočia však môžeme jednoznačne vidiet', ako predlžujúca sa dížka života vplývala a pravdepodobne bude vplývat' na hodnoty prospektívneho veku.

Napríklad línia označená vekom 65 rokov ukazuje, v akom veku (na osi $Y$ ) osoby dosahovali a môžu dosahovat' rovnakú strednú dížku života ako to bolo v roku 2016. Môžeme tak vidiet', že dnešný 65-ročný človek má rovnaký počet rokov života pred sebou ako šest'desiatnik z konca 50. až začiatku 90. rokov 20. storočia. Vel'mi podobne sú na tom aj dnešní šest'desiatnici, ktorých tak môžeme vzhl'adom na ich prospektívny vek označit' ako minulých 55-ročných. Vzhl'adom na pokračujúce zlepšovanie úmrtnostných pomerov v seniorskom veku sa dá očakávat', že stredná dížka života sa bude nad'alej predlžovat', čo sa odzrkadlí aj v hodnotách prospektívneho veku. Z obr. 1 je potom zrejmé, že rovnaký počet rokov života pred sebou ako súčasný šest'desiatnik by mohli mat' v roku 2060 osoby vo veku takmer 68 rokov.

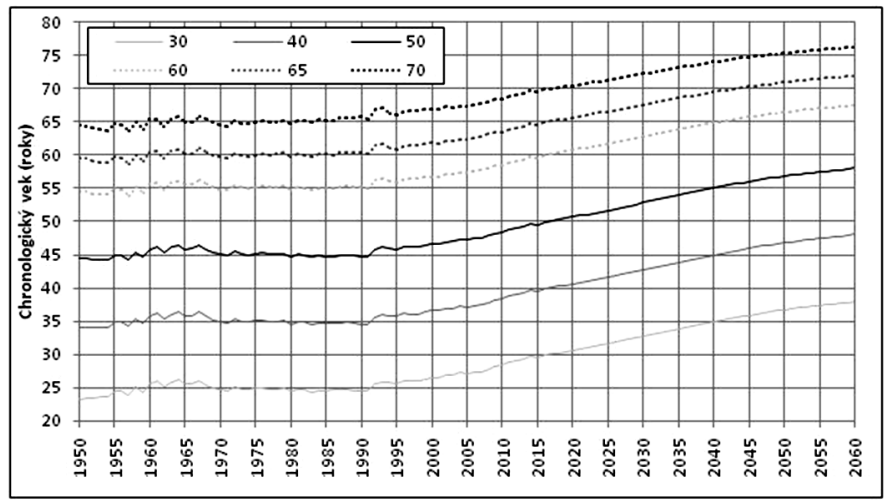

Obr. 1. Vývoj prospektívneho veku v populácii Slovenska pre vybrané vekové skupiny štandardu z roku 2016

Hodnoty konštantného prospektívneho veku na Slovensku v 50. a prvej polovici 60. rokov 20. storočia pomerne rýchlo vzrástli z približne 62 na takmer 64 rokov (obr. 2). V nasledujúcich približne troch desat'ročiach sa však hodnoty konštantného prospektívneho veku (63 rokov) takmer nezmenili. Príčinu je potrebné hl'adat' predovšetkým v stagnácii úmrtnostných pomerov, ked’ stredná dížka života rástla 
len vel'mi pozvol'ne u žien, kým u mužov dochádzalo dokonca k miernemu zhoršovaniu úmrtnostných pomerov (pozri napr. Bleha et al. 2013 a Šprocha a Majo 2016). Od začiatku 90. rokov však opätovne dochádza k dynamickému zlepšovaniu. Ako ukázala podrobná dekompozičná analýza (Bleha et al. 2013), k celkovému naštartovaniu predlžovania života dochádzalo nielen $v$ mladšom, ale aj staršom veku. Preto stredná dížka života rástla aj vo veku nad 60 rokov. Vek, ked' zostávalo ešte 15 rokov života, sa tak posúval, no až na začiatku nového milénia dosiahol hodnotu 65 rokov. Dovtedy teda na Slovensku platilo, že hodnota konštantného prospektívneho veku vnímaná ako alternatívna hranica staroby bola nižšia ako konvenčná hranica vymedzovaná chronologickým vekom 65 rokov (obr. 2). Vd'aka pokračujúcemu zlepšovaniu úmrtnostných pomerov sa posúva do čoraz vyššieho veku a podl'a posledných dostupných údajov z roku 2016 už dosahovala hodnotu približne 67,8 roka. Ked’že kontinuálne znižovanie úmrtnosti vo vyššom veku sa očakáva aj v d'alších desat'ročiach, vek, ked' bude priemernej osobe na Slovensku zostávat' 15 rokov života, sa bude posúvat'. V horizonte prognózy (rok 2060) by mohol dosiahnut' takmer 74,5 roka. Pri naplnení tejto predikcie by v roku 2060 zostával na Slovensku takmer 75-ročnej osobe rovnaký počet rokov života ako 65-ročnej na začiatku 21. storočia. Uvedená informácia má vel'ký význam aj smerom $\mathrm{k}$ nastaveniu veku odchodu do starobného dôchodku. Ak by sme chceli priemernú dížku jeho poberania nastavit' pre všetky kohorty rovnako, a to na 15 rokov, potom by podl'a vývoja konštantného prospektívneho veku muselo dôjst' do roku 2060 ku kontinuálnemu predíženiu až na takmer 75 rokov.

Podiel osôb vo veku 65 a viac rokov na Slovensku v druhej polovici 20. storočia len pozvol'ne rástol z necelých $7 \%$ na $10 \% \mathrm{v}$ polovici 70 . rokov, aby v poslednej dekáde prelomil hranicu $12 \%$. Od tohto momentu sa však očakáva pomerne dynamický nárast, a to až na viac ako jednu tretinu z celej populácie (obr. 3). Podiel osôb so zostávajúcou dížkou života maximálne 15 rokov mal dlho podobný priebeh a úroveň. Až do začiatku 90. rokov 20. storočia bolo ich zastúpenie v slovenskej populácii o niečo častejšie, ked'že sa ich váha zvýšila z približne $8 \%$ na niečo vyše $11 \%$, na ktorej stagnovala $\mathrm{v}$ podstate až do súčasnosti. V nasledujúcich desat'ročiach podl'a stredného variantu prognózy Blehu et al. (2013) však aj pri tomto indikátore starnutia môžeme očakávat' nárast. Ten však ani zd'aleka nebude taký dynamický ako ukazuje predpokladaný vývoj konvenčného podielu osôb vo veku 65 a viac rokov. Podiel osôb so zostávajúcou strednou dížkou života 15 a menej rokov by sa na Slovensku mal na začiatku 30. rokov dostat' nad hranicu $15 \%$ a do konca prognózovaného obdobia by sa mohol priblížit' k úrovni necelých $20 \%$ (obr. 5).

Výraznú dynamizáciu procesu starnutia populácie Slovenska v najbližších rokoch potvrdzuje aj d’alší klasický indikátor - index starnutia. Pomer medzi poproduktívnou a predproduktívnou zložkou v druhej polovici 20. storočia mierne vzrástol z necelých $18 \%$ na takmer $40 \%$. Podl'a posledných dostupných údajov z roku 2016 by však na Slovensku malo pripadat' na 100 osôb vo veku do 20 rokov takmer 73 seniorov vo veku 65 a viac rokov (obr. 4). Daalší vývoj by však mal priniest' spomínané zrýchlenie starnutia, ked' hranica $100 \%$ by mohla byt' podl'a stredného scenára prognózy Blehu et al. (2013) prelomená na konci 20. rokov. Od tohto momentu by v populácii Slovenska mali mat' prevahu osoby vo veku 65 a viac rokov. Nepomer medzi predproduktívnou a poproduktívnou zložkou by sa však mal d'alej prehlbovat' a v horizonte prognózy by index starnutia už mohol dosahovat' takmer $192 \%$. Znamenalo by to, že na jednu osobu vo veku do 20 rokov by pripadali takmer dve osoby vo veku 65 a viac rokov. Čo však hovorí alternatívny prospektívny 
index starnutia? V podstate takmer až do súčasnosti mali oba typy ukazovatel'ov približne rovnaký priebeh a rovnaké hodnoty. Z niečo vyše $20 \%$ sa úroveň prospektívneho indexu starnutia zvýšila na necelých $40 \%$ na konci 20 . storočia. V poslednej dekáde však dynamika nárastu hodnôt konvenčného indexu starnutia bola o niečo vyššia, a preto $\mathrm{v}$ súčasnosti prospektívny index starnutia dosahuje necelých $56 \%$, teda o takmer 17 p. b. nižšiu úroveň ako pri tradičnom indexe starnutia. Diferencia $\mathrm{v}$ dynamike starnutia bude s najväčšou pravdepodobnost'ou pokračovat' aj v d'alších desat'ročiach a na konci prognózovaného obdobia by na 100 osôb vo veku do 20 rokov mohlo pripadat' necelých 113 osôb so zostávajúcou dížkou života 15 a menej rokov. Hranica $100 \%$ by pritom mala byt' podl'a stredného variantu prognózy prelomená až v polovici 21. storočia (obr. 4).

Zat’aženie produktívnej zložky obyvatel'stva Slovenska poproduktívnou sa v podstate až do súčasnosti menilo len v obmedzenom rozsahu. Na začiatku 50. rokov na 100 osôb vo veku 20 - 64 rokov pripadalo len niečo vyše 12 seniorov starších ako 65 rokov, pričom do súčasnosti sa ich váha približne zdvojnásobila. $\mathrm{V}$ posledných rokoch sme svedkami určitého zrýchlenia nárastu hodnôt indexu zat’aženia starým obyvatel'stvom, ktoré bude pokračovat' až do konca prognózovaného obdobia (obr. 5).

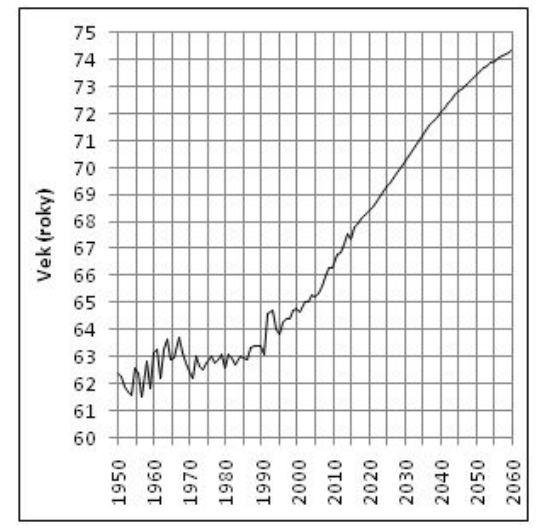

Obr. 2. Vývoj konštantného prospektívneho veku na Slovensku (CPA RLE 15)

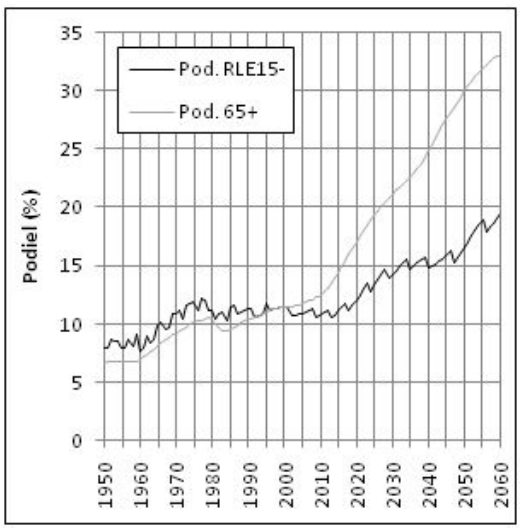

Obr. 3. Podiel osôb vo veku 65 a viac rokov (Pod. 65+) a podiel osôb so zostávajúcou strednou dížkou života 15 a menej rokov

(Pod. RLE 15-)

V roku 2060 by tak malo na 100 osôb v produktívnom veku pripadat' 66 osôb $\mathrm{v}$ poproduktívnom. Ak sa však pozrieme na prospektívnu formu indexu, nájdeme niekol'ko rozdielov. Podobne ako v predchádzajúcich prípadoch, až do začiatku 90. rokov 20. storočia prospektívny index naznačoval vyššiu mieru zat'aženia produktívnej zložky poproduktívnou. $\mathrm{Na}$ druhej strane po určitom náraste vrcholiacom v polovici 70. rokov 20. storočia na úrovni $22-23 \%$, došlo až do súčasnosti k poklesu na 15 - $16 \%$ (obr. 7). V najbližších štyroch desat'ročiach však aj v prípade prospektívnej formy indexu zat’aženia môžeme očakávat' kontinuálny nárast. Ten však bude výrazne menej dynamický, ked’že v horizonte prognózy sa očakáva približne 31 osôb so strednou dlžkou života 15 a menej rokov na 100 osôb vo veku od 20 rokov do veku, ked' ich stredná dížka života ešte bude vyššia ako 15 rokov. 


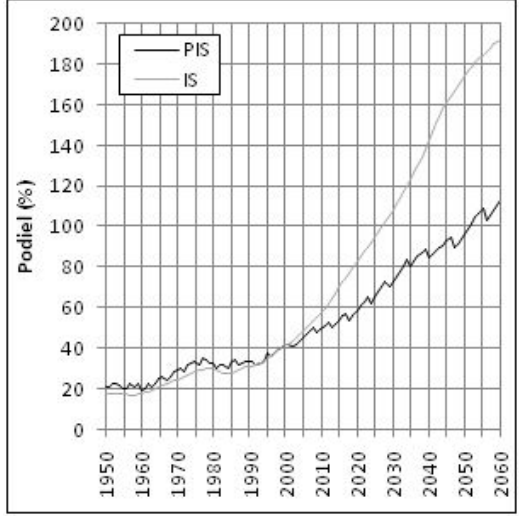

Obr. 4. Vývoj indexu starnutia (IS) a prospektívneho indexu starnutia

(PIS) na Slovensku

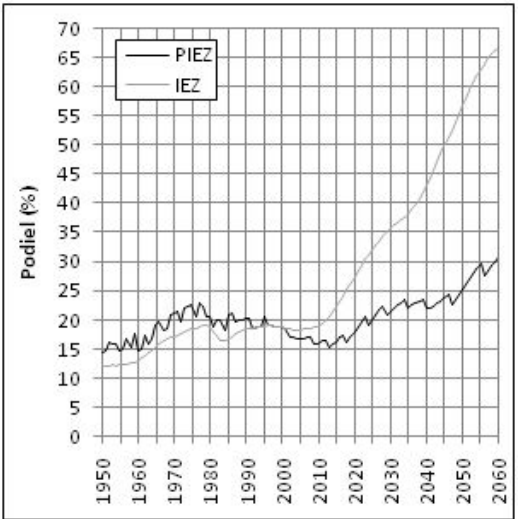

Obr. 5. Vývoj indexu zat’aženia starým obyvatel'stvom (IEZ) a prospektívneho indexu zat’aženia starým obyvatel'stvom (PIEZ)

Chronologický priemerný vek v populácii Slovenska v druhej polovici 20. storočia vzrástol približne z 30 rokov na viac ako 35 rokov (obr. 6). Práve s výrazným poklesom plodnosti a počtu narodených detí v 90 . rokoch 20 . storočia a na začiatku nového milénia a s postupným predlžovaním života je spojená dynamizácia rastu priemerného veku. V súčasnosti už prekračuje hranicu 40 rokov a podl'a stredného variantu prognózy Bleha et al. (2013) by v jej horizonte priemerný obyvatel' Slovenska mohol mat' viac ako 49 rokov. Podobný vývoj zaznamenal aj vekový medián. Z 27 - 28 rokov od druhej polovice 70 . rokov 20 . storočia pomerne dynamicky vzrástol až na súčasných takmer 40 rokov. Ked’že jeho hodnoty rastú ešte rýchlejšie, v horizonte prognózy by polovica osôb na Slovensku mala byt's najväčšou pravdepodobnost'ou staršia ako 50 rokov.

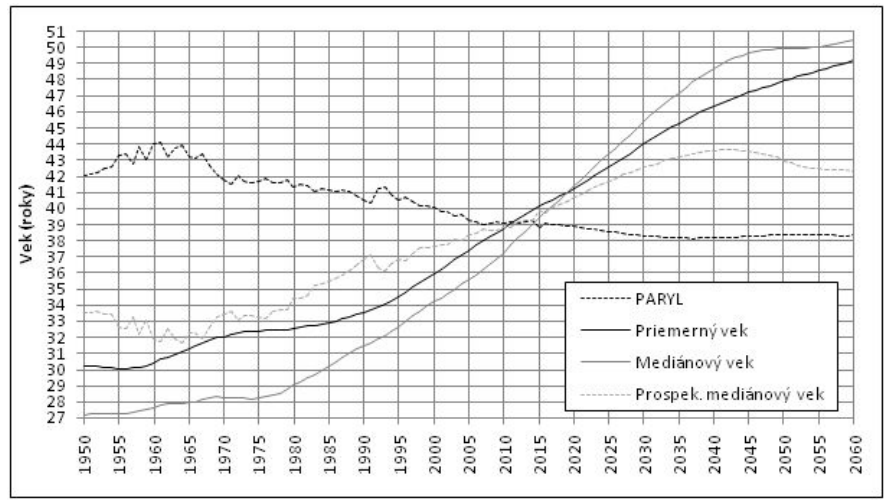

Obr. 6. Vývoj priemerného a mediánového veku, prospektívneho mediánového veku a populačne váženej priemernej strednej dížky života (PARYL) na Slovensku

Podobne ako $\mathrm{v}$ predchádzajúcich prípadoch, aj vážený priemer zostávajúcich stredných dížok života a prospektívny mediánový vek nedosahovali a nebudú dosa- 
hovat' takú dynamiku rastu. $\mathrm{V}$ oboch prípadoch navyše nebudeme ani svedkami kontinuálneho starnutia, ako to signalizujú chronologické varianty týchto indikátorov, pričom môže dôjst' $\mathrm{k}$ ich určitej stagnácii, či dokonca poklesu. Hodnota prospektívneho mediánového veku bola na Slovensku dlhodobo vyššia ako ukazoval konvenčný mediánový vek, no s približne rovnakým trendom. Rast v druhej polovici 20. a na začiatku 21. storočia však vykazoval nižšiu dynamiku, preto sa v súčasnosti hodnoty oboch vyrovnali. V najbližších desat'ročiach síce očakávame postupný rast, no ten nebude ani zd’aleka taký dynamický ako v konvenčnom mediánovom veku. Približne od začiatku 40. rokov 20. storočia dokonca môže dôjst' $\mathrm{k}$ poklesu a následnej stagnácii na úrovni niečo viac ako 42 rokov. Populačne vážený priemer stredných dížok života najprv vykazoval do polovice 60 . rokov 20. storočia mierny nárast na hodnotu 44 rokov, no od tohto momentu registrujeme pozvol'ný pokles. Ten by sa mal zastavit' na začiatku 40. rokov a prejst' do vel'mi mierneho nárastu (obr. 6). V prípade tohto ukazovatel'a si však musíme uvedomit' opačný vzt’ah - čím dlhšia priemerná stredná dížka života, tým mladšia je populácia. Je preto zrejmé, že aj indikátor váženej priemernej strednej dížky života reflektuje hlavné zmeny vo vekovej štruktúre populácie Slovenska, a to v kombinácii $\mathrm{s}$ transformáciou úmrtnostných pomerov.

\section{MEDZINÁRODNÝ KONTEXT STARNUTIA OBYVATELSTVA A POSTAVENIE SLOVENSKA}

Ako sme už uviedli v úvode, štandardné na retrospektívnom veku založené ukazovatele starnutia sa takmer výlučne využívajú na hodnotenie procesu populačného starnutia v medzinárodnom pohl'ade. Musíme si však uvedomit', že nielen v celosvetovom, ale aj európskom priestore existujú pomerne vel'ké rozdiely v úmrtnostných pomeroch (napr. Vallin a Meslé 2004 a Šprocha et al. 2015), ktoré sa premietajú do značných diferencií v hodnotách stredných dížok života, čo znamená opätovne porovnávanie populácií so značne odlišnými charakteristikami (pozri vyššie). Preto prospektívny prístup k procesu starnutia má značný význam aj pri medzinárodnej analýze populačného starnutia. V nasledujúcej časti príspevku sa preto zameriame na stručné zhodnotenie tohto procesu prostredníctvom vybraných prospektívnych a retrospektívnych indikátorov starnutia a pozrieme sa tiež na to, do akej miery nám tieto dve dimenzie dávajú odlišné výsledky. Nemenej dôležitým bude aj zhodnotenie postavenia Slovenska v európskom priestore.

Na obrázku 7 môžeme vidiet' v podstate viac-menej klasickú dichotómiu, kde krajiny severnej a západnej Európy majú najlepšie úmrtnostné pomery, a preto aj zostávajúcich 15 rokov života dosahujú vo vyššom veku. Napríklad vo Francúzsku by podl'a úmrtnostných tabuliek z roku 2015 mali práve 15 rokov života pred sebou osoby vo veku 73,6 roka. V d'alších piatich štátoch (Španielsko, Švajčiarsko, Taliansko, Lichtenštajnsko a Luxembursko) by túto hranicu dosahovali l'udia vo veku viac ako 72 rokov. Naopak v Moldavsku konštantný prospektívny vek 15 rokov dosahujú obyvatelia už vo veku niečo vyše 64 rokov. V Macedónsku je to približne vo veku 65,4 roka a v d'alších šiestich krajinách východnej a juhovýchodnej Európy (Srbsko, Ukrajina, Rusko, Bulharsko, Bielorusko a Čierna Hora) sa konštantný prospektívny vek pohybuje v rozpätí 66,1 - 66,6 roka. Slovensko spolu s Lotyšskom, Litvou a Českom patria ku krajinám, kde tento ukazovatel' dosahuje o niečo priaznivejšie hodnoty $(68,0$ - 68,9 roka), no stále je pomerne hlboko pod priemerom 28 členských štátov EÚ (d'alej EÚ-28), čo predstavuje 71,3 roka. 


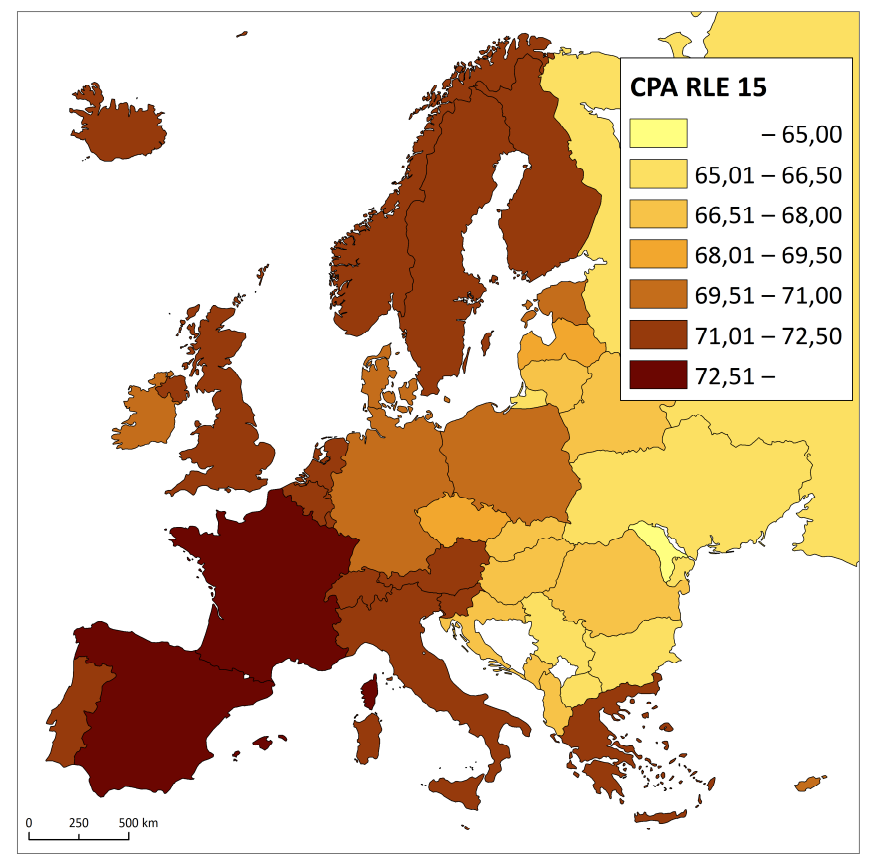

\begin{tabular}{|c|c|}
\hline \multicolumn{2}{|c|}{$\begin{array}{l}\text { Vek, ked' osoba má } \\
\text { zostávajúcu strednú dížku } \\
\text { života } 15 \text { rokov/ } \\
\text { Constant Prospective Age } \\
\text { (CPA RLE 15) }\end{array}$} \\
\hline $\begin{array}{l}\text { EU-28 } \\
\text { Slovensko }\end{array}$ & $\begin{array}{l}71,3 \\
68,0\end{array}$ \\
\hline Najvyššie hodnoty & roky \\
\hline Francúzsko & 73,6 \\
\hline Španielsko & 72,7 \\
\hline Švajčiarsko & 72,5 \\
\hline Lichtenštajsko & 72,2 \\
\hline Taliansko & 72,1 \\
\hline Najnižšie hodnoty & roky \\
\hline Moldavsko & 64,3 \\
\hline Macedónsko & 65,4 \\
\hline Srbsko & 66,0 \\
\hline Ukrajina & 66,2 \\
\hline Rusko & 66,3 \\
\hline
\end{tabular}

Obr. 7. Konštantný prospektívny vek RLE15- v krajinách Európy v roku 2015 Zdroj údajov: EUROSTAT (2015), výpočty autorov.

Podiel osôb vo veku 65 a viac rokov používaný ako jeden z najjednoduchších ukazovatel'ov vekovej štruktúry a starnutia populácie vo všeobecnosti ukazuje, že niektoré krajiny východnej a juhovýchodnej Európy patria skôr k populáciám s najnižším zastúpením tejto vekovej skupiny. Sem je možné zaradit’ aj Slovensko a zo západnej Európy Island a Írsko. Naopak najvyšší podiel osôb vo veku 65 a viac rokov dosahujú juhoeurópske štáty, ale aj Nemecko či Bulharsko, pričom nad priemerom EÚ-28 sa nachádzajú aj severské štáty Fínsko, Švédsko a Lotyšsko. Ak však hodnotíme v populácii podiel osôb, ktorým zostáva podla úmrtnostných tabuliek 15 a menej rokov života, potom sa tento obraz do určitej miery zmení. Najstaršími čast’ami Európy sa stávajú viaceré krajiny Balkánu spolu s Mad'arskom a d’alej je to Lotyšsko, Litva a Nemecko. Práve populácie východnej a juhovýchodnej Európy zaznamenali najväčší prepad (posun) v príslušnosti podl'a kvintilového rozdelenia sledovaného ukazovatel'a v porovnaní so štandardným ukazovatel'om. Na druhej stane, v mnohých krajinách západnej a severnej Európy došlo k zlepšeniu ich postavenia (pozri obr. 8).

Len v 13 európskych krajinách z viac ako štyroch desiatok analyzovaných má miernu prevahu detská zložka nad seniorskou. Najvýraznejšia je táto prevaha v Írsku, Moldavsku, Albánsku a na Islande, kde na 100 detí do 15 rokov pripadá približne 60 - 67 seniorov vo veku 65 a viac rokov. Do tejto skupiny patrí aj Slovensko s indexom starnutia niečo viac ako 91 osôb. Na opačnej strane stáli krajiny južnej Európy spolu s Bulharskom a tiež Nemecko, Lotyšsko a Litva. Ak aplikujeme prospektívny prístup, opätovne môžeme identifikovat' zvýraznenie pozície niektorých balkánskych krajín a Mad'arska. Nepriaznivá situácia nad'alej zostáva 
v Nemecku, Taliansku a v pobaltských štátoch (obr. 9). Aj v tomto prípade platí, že prospektívny index starnutia posúval krajiny bývalého východného bloku skôr ku starším populáciám, kým populácie severnej a niektoré štáty západnej a južnej Európy boli v porovnaní s klasickým indexom mladšie (obr. 9).
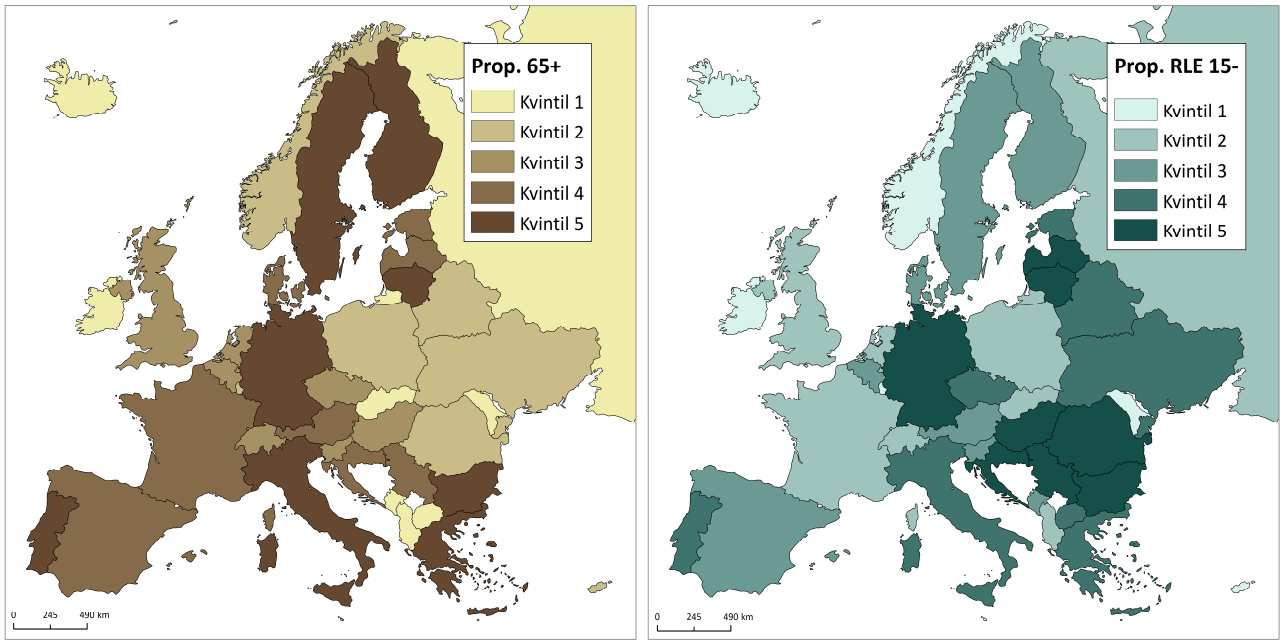

$\begin{aligned} & \text { Podiel osôb vo veku } \mathbf{6 5} \text { a viac rokov/Proportion of the } \\
& \text { Population aged 65+ (Prop. } 65+)\end{aligned}$
\begin{tabular}{lrlr} 
EU-28 & 18,9 & Slovensko & 14,0 \\
\hline Najvy̌šie hodnoty & $\%$ & Najnižšie hodnoty & $\%$ \\
\hline Taliansko & 21,7 & Moldavsko & 10,3 \\
Nemecko & 21,0 & Albánsko & 12,4 \\
Grécko & 20,9 & Macedónsko & 12,7 \\
Portugalsko & 20,3 & Írsko & 12,9 \\
Bulharsko & 20,0 & Rusko & 13,5 \\
& & &
\end{tabular}

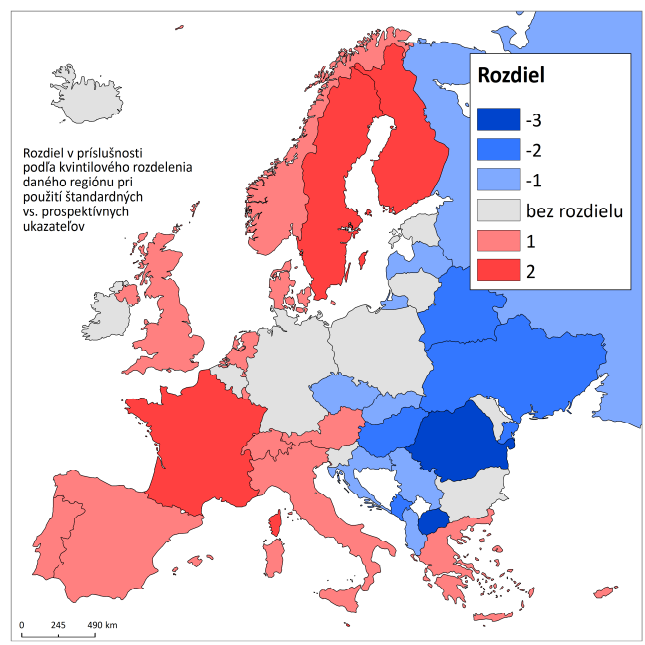

Podiel osôb so zostávajúcou strednou dížkou života 15 a menej rokov/Proportion of Ages With Remaining Life Expectancy of 15 Years or Less (Prop. RLE 15-)

\begin{tabular}{lrlr} 
EU-28 & 11,6 & Slovensko & 9,9 \\
\hline Najvyššie hodnoty & $\%$ & Najnižšie hodnoty & $\%$ \\
\hline Bulharsko & 17,2 & Lichtenštajsko & 6,9 \\
Srbsko & 15,6 & Írsko & 7,2 \\
Chorvátsko & 15,2 & Luxembursko & 7,3 \\
Lotyšsko & 15,0 & Island & 7,7 \\
Litva & 14,7 & Cyprus & 8,9
\end{tabular}

Obr. 8. Podiel osôb vo veku 65 a viac rokov, podiel osôb so zostávajúcou strednou dížkou života 15 a menej rokov a ich rozdiel v krajinách Európy v roku 2015

Zdroj údajov: EUROSTAT (2015), výpočty autorov.

Produktívna zložka populácie je seniorskou zat’ažená vo zvýšenej miere najmä v krajinách bývalého západného bloku. Vo všeobecnosti s výnimkou niektorých prípadov (Írsko, Nórsko a Island) väčšina z nich spadá do piateho kvintilu. Naopak, väčšina krajín bývalého východného bloku (vrátane Slovenska) dosahovala nízku úroveň ekonomického zat'aženia starým obyvatel'stvom. Aj v tomto prípade sa situácia pomerne výrazne zmení použitím prospektívneho prístupu. Najvyššie hodnoty 
prospektívneho indexu ekonomického zat'aženia starým obyvatel'stvom opätovne dosahovali mnohé balkánske krajiny s Mad'arskom, d’alej Nemecko a Litva s Lotyšskom. Rovnako platí, že väčšina populácií západnej, južnej a severnej Európy sa v prospektívnom pohl'ade posúva $\mathrm{k}$ mladším populáciám, kým $\mathrm{v}$ štátoch bývalého východného bloku sa naopak prehlbuje starnutie ich populácií (obr. 10).
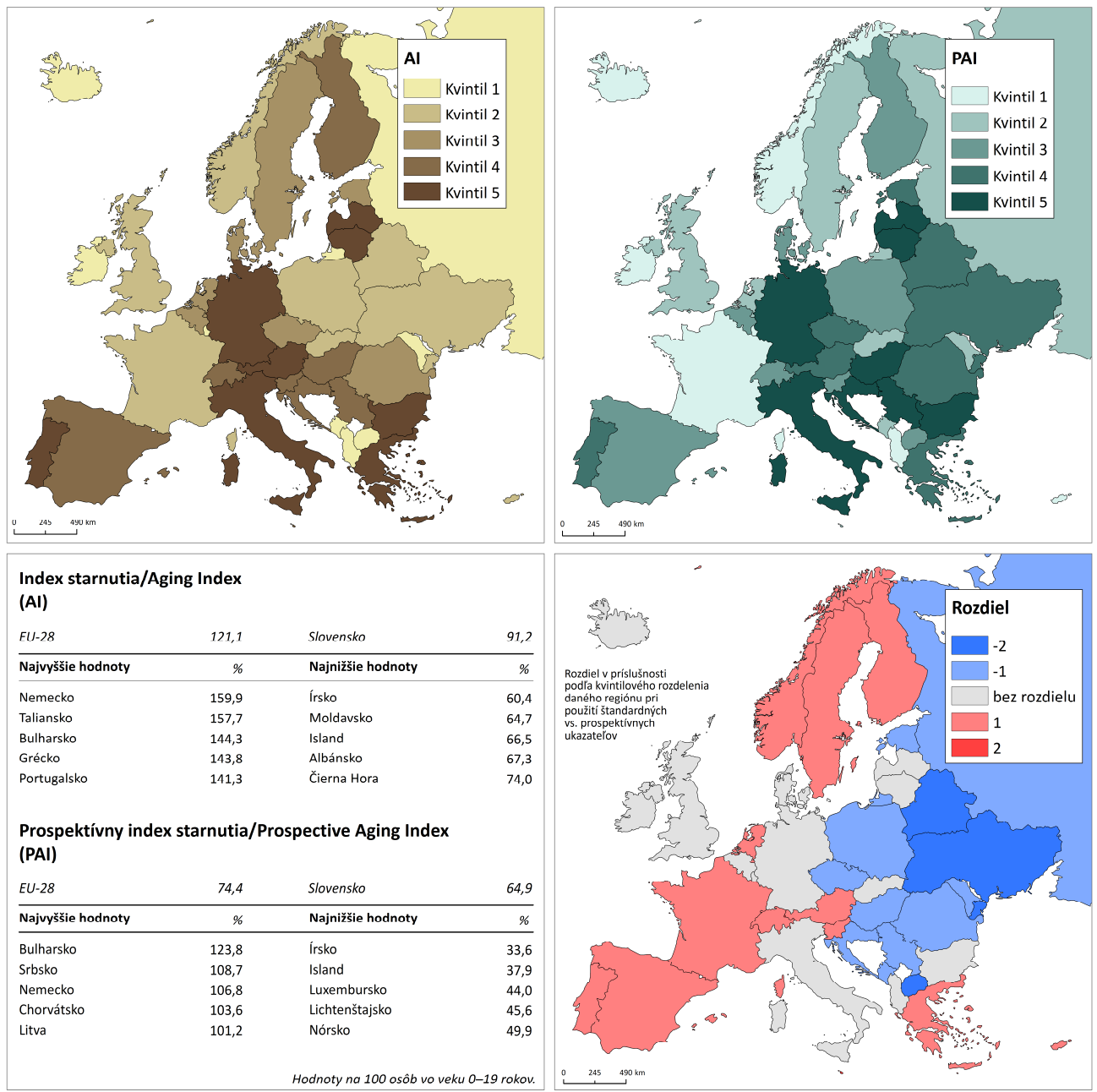

Prospektívny index starnutia/Prospective Aging Index (PAI)

\begin{tabular}{lrlr} 
EU-28 & 74,4 & Slovensko & 64,9 \\
\hline Najvyššie hodnoty & $\%$ & Najnižšie hodnoty & $\%$ \\
\hline Bulharsko & 123,8 & Írsko & 33,6 \\
Srbsko & 108,7 & Island & 37,9 \\
Nemecko & 106,8 & Luxembursko & 44,0 \\
Chorvátsko & 103,6 & Lichtenštajsko & 45,6 \\
Litva & 101,2 & Nórsko & 49,9
\end{tabular}

Obr. 9. Index starnutia, prospektívny index starnutia a ich rozdiel v krajinách Európy $\mathrm{v}$ roku 2015

Zdroj údajov: EUROSTAT (2015), výpočty autorov. 

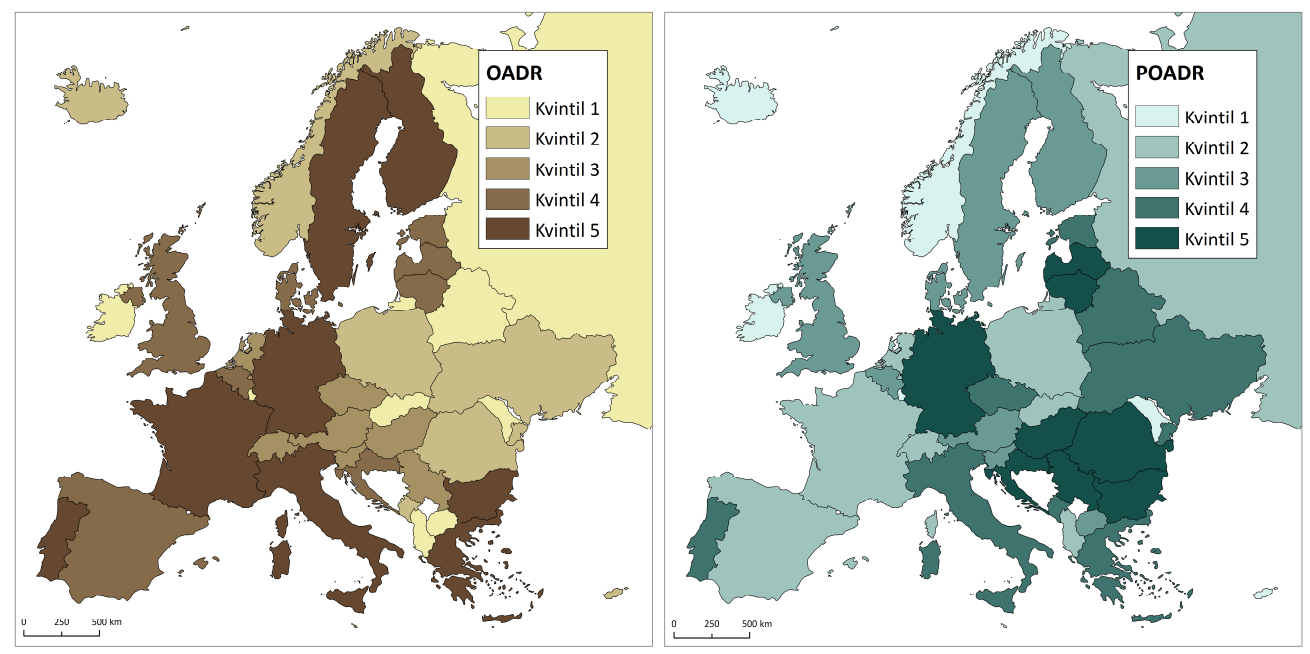

\begin{tabular}{|lrlr|}
\hline \multicolumn{3}{|l|}{ Index ekonomického zat́aženia starými osobami/ } \\
Old-Age Dependency Ratio (OADR) \\
FU-28 & 31,4 & Slovensko & \\
\hline Najvyššie hodnoty & $\%$ & Najnižšie hodnoty & $\%$ \\
\hline Taliansko & 36,4 & Moldavsko & 15,3 \\
Grécko & 35,1 & Macedónsko & 19,7 \\
Nemecko & 34,6 & Albánsko & 20,5 \\
Fínsko & 34,4 & Rusko & 20,7 \\
Švédsko & 34,0 & Slovensko & 21,4 \\
& & & \\
\hline
\end{tabular}

Prospektivny index ekonomického zat́aženia starými osobami/ Prospective Old-Age Dependency Ratio (POADR)

\begin{tabular}{lrlr} 
EU-28 & 17,2 & Slovensko & 14,3 \\
\hline Najvy̌̌šie hodnoty & $\%$ & Najnǐ̌šie hodnoty & $\%$ \\
\hline Bulharsko & 26,6 & Lichtenštajsko & 9,5 \\
Srbsko & 24,1 & Luxembursko & 10,4 \\
Chorvátsko & 23,7 & Írsko & 11,1 \\
Loty̌sko & 22,9 & Island & 11,8 \\
Litva & 22,7 & Malta & 13,0
\end{tabular}

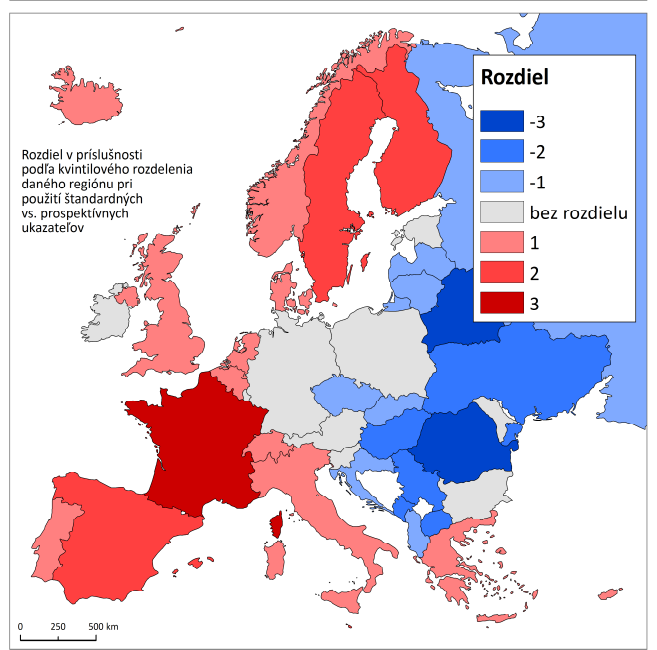

Obr. 10. Index ekonomického zat'aženia starým obyvatel'stvom, prospektívny index ekonomického zat’aženia starým obyvatel'stvom a ich rozdiel v krajinách Európy v roku 2015

Zdroj údajov: EUROSTAT (2015), výpočty autorov.

\section{ZÁVER}

Štúdia si vytýčila ako hlavný ciel' predstavit' slovenskej vedeckej obci nové možnosti analýzy populačného starnutia prostredníctvom sledovania prospektívnej dimenzie veku. Ten popri chronologickom veku predstavuje dva základné pohl'ady naň. V súčasných prácach venujúcich sa problematike procesu starnutia na Slovensku výlučne dominuje chronologický vek. Ten predstavuje počet prežitých rokov od narodenia, kým prospektívny nás informuje o potenciálnej zostávajúcej dížke života. Obe dimenzie sa tak navzájom nevylučujú, nie sú alternatívami, ale skôr komplementárnymi prístupmi, ktoré výrazne prehlbujú naše poznanie. Neznamená 
to, že by naša pozornost' mala byt' orientovaná len na otázky prospektívneho veku, ale je prinajmenšom nutné tejto problematike začat' na Slovensku venovat' pozornost' a postupne ju rozpracovávat' aj v našich podmienkach. Odklon od tradičných konvenčných prístupov, ku ktorému začína vo svetovej vede dochádzat' v posledných približne dvoch desat'ročiach, je vzhl'adom na vysokú aktuálnost' v prípade Slovenska nutné pozorne sledovat' a rozvíjat'. Predložená štúdia však ani zd'aleka nemôže toto poslanie naplnit' a predstavuje skôr len akýsi úvod - nasmerovanie pre záujemcov o túto problematiku. Stav jej rozpracovanosti, smery d'alšieho rozvoja a postupný prechod $\mathrm{k}$ multidisciplinárnemu poňatiu sú už $\mathrm{v}$ súčasnosti mimo možnosti kolektívu autorov. Sanderson a Scherbov (2013, p. 675) dokonca upozorňujú, že v celom komplexe novovznikajúcich prác je možné identifikovat' novo sa formujúcu paradigmu v konceptualizácii problematiky populačného starnutia.

Ako ukázala aplikácia prospektívnych indikátorov starnutia, tieto na Slovensku mali v porovnaní s konvenčnými ukazovatel'mi často výrazne odlišnú úroveň a v mnohých prípadoch sa vyznačovali aj odlišnou dynamikou vývoja, či dokonca nie úplne rovnakými vývojovými trendmi. Možno preto povedat', že tieto ukazovatele nie sú len iným meraním toho istého javu, ale skôr doplnajú analýzu procesu populačného starnutia, poukazujú na novú dimenziu demografického starnutia reflektujúcu jeho viaceré biologické a behaviorálne aspekty. Jednoznačne môžeme aj v prípade Slovenska potvrdit', že aj napriek odlišným demografickým podmienkam v porovnaní s najvyspelejšími krajinami bývalého západného bloku, pri rýchlom raste strednej dížky života prospektívne indikátory naznačujú pomalšiu dynamiku starnutia ako je to $\mathrm{v}$ prípade ich merania prostredníctvom konvenčných prístupov. Tento záver má vel'mi dôležité praktické konzekvencie. Na jednej strane poukazuje na to, že často až katastroficky prezentované vývojové trendy v oblasti starnutia (napríklad z pohl'adu počtu a podielu seniorov, ekonomického zat'aženia a pod.) nemusia ani zd'aleka nadobúdat' také rozmery, ak sa na problematiku starnutia a najmä vymedzenia populácie starých osôb pozrieme komplexnejšie a nielen fixným stanovením chronologickej vekovej hranice. Na druhej strane viaceré analýzy potvrdzujú, že nie je možné porovnávat' súčasné, budúce a minulé skupiny seniorov. Ide a pôjde $z$ viacerých uhl'ov pohl'adu o úplne odlišné populácie, okrem iného aj z hl’adiska zostávajúcej dĺžky života. Práve predlžovanie života vo vyššom veku sa ukazuje byt' jednou z kl'účových charakteristík, ktorá výraznou mierou ovplyvňuje d'alšie osobnostné charakteristiky a bude zohrávat' aj v budúcnosti rozhodujú$\mathrm{cu}$ úlohu $\mathrm{v}$ procese demografického starnutia. Preto zohl'adnenie týchto zmien $\mathrm{v}$ podobe aplikácie nových prospektívnych indikátorov je prvým krokom $\mathrm{k}$ tomu, ako si uvedomit' dôležitost' tejto dimenzie. Viaceré zahraničné multidsciplinárne štúdie však ukazujú, že s prospektívnym vekom sa úzko spájajú nielen osobnostné charakteristiky, ale výrazne ho ovplyvňuje aj oblast' výdavkov na zdravotnú starostlivost', dôchodkový systém, rozhodovania o výkone niektorých typov operácií, pridelenia niektorých sociálnych pracovníkov a pod. Širší pohl'ad na populačné starnutie, ktorý prináša so sebou aplikácia retrospektívneho i prospektívneho prístupu, je klúčcovým pre správne pochopenie a formovanie vhodných, udržatel'ných a zmysluplných opatrení reagujúcich na výzvy, ktoré tento proces pre slovenskú spoločnost' prináša.

Medzinárodné porovnanie procesu starnutia retrospektívnymi a prospektívnymi ukazovatel'mi poukázalo na pomerne značné rozdiely v úrovni tohto procesu, ako aj na dost' odlišné pohl'ady získané ich aplikáciou. Vo všeobecnosti môžeme pove- 
dat', že pri klasických indikátoroch boli staršími najmä populácie bývalého západného bloku, kým z východného sem patrili len niektoré štáty (Bulharsko, Lotyšsko a Litva). Aplikáciou prospektívnych ukazovatel'ov sa medzinárodný obraz $\mathrm{v}$ európskom priestore do určitej miery zmenil, ked' jednoznačne dochádza k posunu juhovýchodných a východných štátov Európy do skupiny krajín so staršími populáciami (najmä vzhl'adom na ich nízke hodnoty konštantného prospektívneho veku), kým západná a severná Európa sa ukazuje byt' mladšia (ked’že má aj lepšie úmrtnostné pomery). V prípade Slovenska $\mathrm{k}$ výraznejším posunom nedochádza a bez ohl'adu na použitý prístup $\mathrm{k}$ procesu starnutia zatial' patrí $\mathrm{v}$ európskom priestore $\mathrm{k}$ mladším populáciám. Existencia značných regionálnych rozdielov $\mathrm{v}$ úmrtnostných pomeroch a vekovej štruktúre však naznačuje, že nielen národná, ale najmä regionálna úroveň predstavuje pre samotnú analýzu procesu populačného starnutia dôležitý aspekt. Vzhl'adom na vyššiu náročnost' vstupných údajov je konštrukcia prospektívnych indikátorov pre regióny Slovenska a Európy zložitejšia a predstavuje tak výzvu pre d'alší výskum.

Príspevok je čiastkovým výstupom z projektu VEGA č. 1/0113/17 „Populačná a rodinná politika na Slovensku v 20. a 21. storoči”.

\section{LITERATÚRA}

ATCHLEY, R. (1982). Retirement as a social institution. Annual Review of Sociology, 8, 263-287.

BALLOD, C. (1913). Grundriss der Statistik: enthaltend Bevoelkerungs-, Wirtschafts-, Finanz- und Handels- Statistik. Berlin (J. Guttentag).

BASTEN, S. (2013). Redefining old age and dependency in East Asia: is prospective aging a more helpful concept? A sian Social Work and Policy Review, 7, 242-248.

BASTEN, S., SCHERBOV, S., SANDERSON, W. C. (2015). Remeasuring ageing in Southeast Asia. A sian Population Studies, 11, 191-210.

BLEHA, B., ŠPROCHA, B., VAŇO, B. (2013). Prognóza populačného vývoja Slovenskej republiky do roku 2060. Bratislava (INFOSTAT).

BONGAARTS, J. (2006). How long do we live. Population and Development Review, 32, 605-626.

CUARESMA, J. C., LÁBAJ, M., PRUŽINSKÝ, P. (2014). Prospective ageing and economic growth in Europe. The Journal of the Economics of Ageing, 3, 50-57.

EUROSTAT (2015). Population projections at national level, [Online]. Dostupné na: http:// ec.europa.eu/eurostat/data/database [cit: 05-01-2018].

GAVRILOV, L. A., HEUVELINE, P. (2003). Aging of population. In Demeny, P., McNicoll, G., eds. The encyclopedia of population. New York (Macmillan), pp. 32-37.

HERSCH, L. (1944). De la démographie actuelle à la démographie potentielle. Melange des Études Economiques Offertes à William Rappard. Genève (Librairie de l'Université).

KLAPKOVÁ, M., ŠÍDLO, L., ŠPROCHA, B. (2016). Koncept prospektivního věku a jeho aplikace na vybrané ukazatele demografického stárnutí. Demografie, 58, 129-141.

LUTZ, W. (2009). The demography of future global population aging: indicators, uncertainty, and educational composition. Population and Development Review, 35, 357-365.

LUTZ, W., SANDERSON, W. C., SCHERBOV, S. (2008a). Global and regional population ageing: how certain are we of its dimensions? Population Ageing, 1, 75-97.

LUTZ, W., SANDERSON, W. C., SCHERBOV, S. (2008b). The coming acceleration of global population ageing. Nature, 451, 716-719.

OECD (2011). Pensionable age and life expectancy, 1950-2050. In OECD, ed.. Pensions at a glance 2011: retirement-income systems in OECD and G20 Countries. Paris (OECD), pp. 19-38. 
OEPPEN, J., VAUPEL, J. (2002). Broken limits to life expectancy. Science, 296, 10291031.

PANUSCH, N., PERITZ, E. (1996). Potential demography: a second look. European Journal of Population 12, 27-39.

RIFFLE, T. (2015). The force of mortality by life lived is force of increment life left in stationary populations. Demographic Research, 32, 827-834.

SANDERSON, W. C., SCHERBOV, V. (2005). Average remaining lifetimes can increase as human populations age. Nature, 435, 811-813.

SANDERSON, W. C., SCHERBOV, V. (2007). A new perspective on population aging. demographic research. Demographic Research, 16, 27-58.

SANDERSON, W. C., SCHERBOV, V. (2008). Rethinking age and aging. Population Bulletin, 63(4), 3-16.

SANDERSON, W. C., SCHERBOV, V. (2010). Remeasuring aging. Science, 329, $1287-$ 1288.

SANDERSON, W. C., SCHERBOV, V. (2013). The characteristics approach to the measurement of population aging. Population and Development, 39, 4, 673-685.

SANDERSON, W. C., SCHERBOV, A. (2015). Are we overly dependent on conventional dependency ratio? Population and Development Review, 41, 687-708.

SHOVEN, J. B. (2007). New age thinking: alternative ways of measuring age, their relationship to labor force participation, government policies and GDP. NBER Working Paper, National Burreau of Economic Research, Cambridge, MA.

SHOVEN, J. B., GODA, G. S. (2010). Adjusting government policies for age inflation. In Shoven, J. B., ed. Demography and the economy. Chicago (The University of Chicago Press), pp. 143-162.

SCHERBOV, S., SANDERSON, W. C. (2016). New approaches to the conceptualization and measurement of age and aging. Journal of Aging and Health, 28, 1159-1177.

SPIJKER, J. (2015). Alternative indicators of population ageing: an inventory. Working Papers, 4/2015, Vienna Institute of Demography.

ŠPROCHA, B., MAJO, J. (2016). Storočie populačného vývoja Slovenska I.: demografické procesy. Bratislava (INFOSTAT).

ŠPROCHA, B., ŚIDLO, L., BURCIN, B. (2015). Úroveň úmrtnosti na Slovensku a v Česku v európskom pohl'ade. Geografický časopis, 67, 25-43.

UNITED NATIONS (2001). World population ageing. Department of economic and social affairs population division. New York (United Nations).

UNITED NATIONS (2015). World population ageing. Department of economic and social affairs population division. New York (United Nations).

VALLIN, J., MESLÉ, F. (2004). Convergence and divergences in mortality. A new approach to health transition. Demographic Research, Special Collection, 2, 11-44.

Branislav Šprocha, Luděk Šídlo, Michaela Klapková, Pavol Ďurček

\section{NEW APPROACHES TO ASSESSING THE POPULATION AGEING PROCESS AND THEIR APPLICATION FOR SLOVAKIA AND EUROPE}

The population ageing process has become one of the most important demographic, social, economic and health factors which affects and will affect the functioning of the whole Slovak society in the 21 st. century. The main purpose of this article was to present the new approach to the process of population ageing based on the concept of prospective age. We have pointed out that every person has two dimensions of age. The first named chronological age is the most commonly used and represents the number of years a person has already lived since birth. The second is a new concept of prospective age based on the forward-looking approach to the ageing process. The basic character of prospective age is that it is a time-horizon consistent indicator, because all people with the same prospective 
age have the same expected number of years ahead of them. Everyone with the same prospective age has the same expected remaining years of life. Traditional indicators of population ageing, such as ageing index, old-age dependency ratio, average or median age based on chronological age give us an incomplete, often distorted picture of the aging process and can thus contribute to problematic political decisions.

If we use chronological age and chronological age-based indicators of ageing, we assume implicitly that people of the same age in different years or populations would behave similarly. It is hardly conceivable to assume that the current 60 -year-olds are the same as in the early 1950s. However, there are significant changes in the life expectancy and many behavioural characteristics are linked to the remaining number of years of life. This assumption is not entirely correct. Prospective and retrospective age are complementary dimensions and quantify two different aspects of the ageing population. Supplementing chronological age with an approach that takes into account the changing life expectancy allows us to analyze ageing more comprehensively and more accurately.

Using retrospective and prospective indicators (constant prospective age, proportion at ages with remaining life expectancies of 15 years or less, prospective old-age dependency ratio, prospective ageing index, prospective median age and population average remaining years of life) in time on the example of Slovakia gives us very important findings. First of all the conclusions of our analysis confirm the increasing dynamics of the ageing process in Slovakia in the last two decades and provide the assumption of its further increase in the near future, not only from a retrospective but also from a prospective age perspective. On the other hand, the development and extent of ageing is significantly less pronounced in the case of a prospective dimension. In some cases (e.g. prospective median age and prospective old-age dependency ratio), we can identify stagnation or moderate decline in the values of these indicators. This is in contradiction with the image that is offered by chronologically-based indicators. The concept of prospective age is not simply another way of measuring the population ageing process, but in connection with standard indicators presents population ageing in a new dimension that better illustrates the biological and behavioural aspects of ageing. Given the great importance of population aging for the future development of Slovak society, it is therefore very important to pay attention to this issue. 
